\title{
Müşteri İlişkileri Yönetiminin Müşteri Sadakati Üzerine Etkisi: Bankacılık Sektörü Üzerine Bir Alan Araştırması
}

Köksal Koçer*

\begin{abstract}
$\ddot{O} z$
$B u$ çalısmanın amacl, bankacılık sektöründe müşteri ilişkileri yönetiminin müşteri sadakatine etkisini incelemektir. Araştırmada veri toplama yöntemi olarak anket tekniğ i kullanılmıştır. Anket çalışması Aydın ilinin Kuşadası ilçesinde bulunan kamu ve özel bankaların müşterilerine uygulanmıştır. Araştırma için sekiz hipotez belirlenmiş ve hipotezlerin doğruluğunu test etmek için regresyon analizi, korelasyon analizi, çok yönlü varyans analizi (MANOVA) ve faktör analizi uygulanmıştır. Sonuç olarak, bankacılık alanında müşteri ilişkileri yönetimi uygulamalarının müşteri sadakati üzerinde pozitif etkiye sahip olduğu bulunmuştur. Fakat elde edilen sonuçlar ile genelleme yapılamayacağına inanılmaktadır.
\end{abstract}

Anahtar Kelimeler: Müşteri İlişkileri Yönetimi, Müşteri Sadakati, Bankacılık Sektörüu.

\section{The Effect of Customer Relationship Management on Customer Loyalty: A Field Study on The Banking Sector}

\begin{abstract}
The purpose of this study is to examine the impact of Customer Relationship Management on customer loyalty in the banking sector. In this research, questionnaire technique was used in order to collect data. The survey was conducted on public and private bank customers in Kusadasi district of Aydin Province. Eight hypotheses were identified in the research. Regression analysis, correlation analysis, multi-way analysis of variance (MANOVA) and factor analysis were used in order to test the accuracy of the hypothesis. The results revealed that customer relationship management applications have a positive effect on customer loyalty in banking sector. However, this result can not be generalized for the whole population.
\end{abstract}

Keywords: Customer Relationship Management, Customer Loyalty, The Banking Sector.

\section{Gíriş}

Rekabetin yoğun olarak yaşandığı ve tüketicilerin/hizmet alanların bilgi ve tecrübelerinin giderek arttığ1 günümüz koşullarında Müşteri İlişkileri Yönetimi (MiY) işletmeler için giderek önem kazanan bir kavram haline gelmiştir. Henry Ford'un "Siyah olmak koşulu ile müşteriler satın alacakları otomobilin rengini seçebilirler" (Saydan, 2004: 158) sözünde de anlattığı gibi ürettiğimi satarım anlayışı küreselleşen dünyamızda artık geçerliliğini kaybetmiş ve müşterinin istek ve ihtiyaçlarını temel alan modern pazarlama anlayışı doğmuştur.

Henry Ford'un sözüne karşılık olarak Robert Bosch'un “İnsanların güvenini kaybetmektense para kaybetmeyi tercih ederim." (Seçkin ve Demirel, 2009: 179) sözü işletmeler tarafından dikkate alınması gereken bir özdeyiştir. Müşterilerinin güvenini sağlayıp onların sadakatini kazanan işletmelerin rakiplerine karşı rekabet üstünlüğü sağlayacağı ve bir adım önde olacağı, işletmeler tarafından benimsenmesi gereken en temel stratejilerden biri olarak karşımıza çıkmaktadır. 
Modern pazarlama anlayışında küresel rekabet ortamının yıkıcı gücü işletmeleri müşteri odaklı pazarlama stratejileri benimsemesine ve uygulamasına yöneltmiştir. İşletmeler, rakipleri karşısında rekabet avantajı sağlaması ve bu yıkıcı gücün altında ezilmemesi için müşterilerinin istek ve ihtiyaçlarını karşılaması hatta bir adım önde olarak bu istek ve arzuları önceden tahmin edip müşterilerine sunması zorunluluk haline gelmiştir.

Müşteriler, işletmeler için en değerli varlıklar olduğu gibi işletmelerin devamlılığı sağlayabilmek için kilit noktasıdır. Müşterisi olmayan firma için satış ve dolayısıyla kar söz konusu olamaz. Bu yüzden müşteri ile iyi ilişkiler sürdürülmesi, işletmenin hayati sorunlarındandır (Bircan, Acayıp ve Okursoy, 2014: 648). Bu sebepten dolayı işletmeler müşteri odaklı bir pazarlama anlayışı benimsemişlerdir. İşletmenin üretim hattından başlayıp satış sonrası hizmetlere varıncaya kadar olan bütün bölümlerde aynı anlayışı benimsemeleri ve bütün çalışanlarıyla aynı anlayışı paylaşmaları gerekmektedir. Bu anlayışı benimsemeyen, müşteri istek ve ihtiyaçlarını göz ardı eden bütün işletmelerin zamanla rekabetin yıkıcı gücüne dayanamayıp küçülerek yok oldukları görülmektedir.

Hizmet yoğun sektörlerde Müşteri İlişkileri Yönetimi kavramının önemi daha çok artmaktadır. Müşterilerle ilişkisel bağ kurmak, güven duygusu aşılamak, müşteri sadakatini sağlamak ve uzun vadeli ilişkiler kurarak karlılığı arttırmak için Müşteri İlişkileri Yönetimi işletmeler için önem arz eden bir kavram olmayı korumaktadır. Hizmet yoğun sektörlerden biri olan bankacılık alanında bankaların en önemli varlıklarının müşteriler olduğu düşünüldüğünde bu kavramı bankacılık alanında faaliyet gösteren işletmelerin kesinlikle göz ardı edemeyeceği su götürmez bir gerçektir.

Çalışmada, MiY uygulamalarının müşteri sadakati üzerine etkisi araştırılmıştır. Daha önce yapılan çalışmaların ışı̆̆ında, konunun öneminin vurgulanması amaçlanarak bankacılık sektörü üzerine bir araştırma yürütülmüştür. "Müşterilerin MIY algılamalarının hangileri ne derece öneme sahiptir? , Müşterilerin sadakat konusunda hem fikir oldukları kriterler nelerdir? , Müşterilerin sadakat konusunda en çok önem verdikleri kriterler nelerdir?, MIY ile sadakat arasında nasıl bir ilişki vardır?" sorularına yanıt aranmaya çalışılmıştır. Araştırmada kullanılacak verilerin elde edilmesi için anket yöntemi kullanılmıştır. Elde edilen sonuçların literatüre ve konu hakkında bilgi sahibi olmak isteyen herkese faydalı olması hedeflenmektedir.

\section{LITERATÜR}

\subsection{Müşteri İlişkileri Yönetimi Kavramı}

Müşteri İlişkileri Yönetimi kavramına bakmadan önce bu kavramın temelini oluşturan müşteri kavramına kısaca göz atmak gerekmektedir. Türk Dil Kurumunda müşteri kavramının karşılığına bakıldığında "Hizmet, mal vb. alan ve karşılığında ücret ödeyen kimse" (http://www.tdk.gov.tr, Erişim: 02.01.2016) tanımı yapılmaktadır. Müşteriler aldığı ürün veya hizmet karşılığında bir ücret ödemeye razı olan kişilerdir. 
Aynı zamanda ücreti öderken bu alışveriş karşılığında memnun kalmayı istemektedirler.

Müşteri İlişkileri Yönetiminin ihtiyacının temelinde kar amaçlı işletmelerin müşteri ile temas noktalarındaki performansı yükseltmeye yönelik çalışmalar olmakta ve bu müşterilerin ihtiyaçlarını anlama, ona uygun ürünün ortaya konulması, hatta satılması ve en son olarak üretilmesini zorunlu kılmaktadır (Imhoff, Loftis ve Riger 2001: 28). Müşteri İlişkileri Yönetimi, bir işletmenin tüm birimleri ve çalışanları tarafından tüm benliğinde hissetmesi ve uygulaması gereken yaklaşım felsefesidir. Geniş anlamda baktığımızda MIY olgusunun kurumlarca bir yaşam tarzı olarak benimsenmesi görülmektedir (Kotler, 2003: 36).

\subsubsection{Müşteri İlişkileri Yönetiminin Tanımı ve Önemi}

Müşteri İlişkileri Yönetimi, "MİY” veya İngilizce'si “Customer Relationship Management" yani kısaca "CRM" gibi kavramlarla kullanılan müşteri odaklı bir şirket yönetim stratejisidir (Özdağoğlu, Özdağoğlu ve Öz, 2008: 368). Müşteri ilişkileri yönetimi, eski müşteriler ile ilişkileri geliştirmek ve onlarda sadakati sağlamak amacıyla, müşterilerin bireysel ihtiyaçları için ürünleri geliştirmek ve hizmetleri uyumlaştırarak, farklı müşterilere farklı açılardan yaklaşıp onları anlamak, etkin ve verimli şekilde yeni müşterileri işletmeye çekerek, karları arttırmaya katkı sağlayan bir iş süreci ve bilgi teknolojileri modelidir (Liyun vd., 2008: 34).

Müşteri İlişkileri Yönetimi, müşteriler hakkında olabilecek en ayrıntılı bilgileri toplamak, bu müşterileri çok ince ayrımlarla bölümlendirmek, bu bölümleri karlılıklarına göre ayrıştırmak, karlı olan müşterilere yapılacak ekstra yatırımın seviyesini belirlemek ve her müşteriye ayrı ve özel pazarlama stratejisi uygulamak olarak tanımlanabilir (Yurdakul ve Karahan, 2010:134). “Müşteri ilişkileri yönetimi; kârlı müşteriler elde etmek, tutmak ve bunları çoğaltma sürecidir. Müşteri ilişkileri yönetimi, uzun vadeli değeri optimize etmek için müşterileri seçme ve yönetme iş yapma stratejisidir"'(Özilhan, 2010: 22). Müşteri İlişkileri Yönetimi işletmeler için önem verilmesi gereken bir kavramdır. Bu kavramın önemini anlayan ve küreselleşen ekonomide pastadan büyük pay almayı hedefleyen işletmeler müşterilerine sundukları farklılaşmış ürün veya hizmetlerle rakiplerini geride bırakacaklar ve amaçlarına ulaşacaklardır. Farklılaştırılmış müşteri ilişkileri yönetimi faaliyetleriyle, müşterilerine onların değerli olduğunu, işletme için önem arz ettiklerini fark ettiren işletmeler kıyasıya rekabetin yaşandığı günümüz ekonomisinde ayakta kalabileceklerdir.

\subsubsection{Müşteri İlişkileri Yönetiminin Amaçlan}

İşletmeler, müşteri ilişkileri yönetimi uygulama süreçlerinde belli bir takım amaçları gerçekleştirmeyi hedefler. Bu amaçlar; müşteri memnuniyeti sağlamak, müşteri sadakati oluşturmak, müşteriye değer yaratmak ve müşteri sürekliliği sağlamaktır (Gödekmerdan ve Deniz, 2010a: 244). Müşteri ile temas kurulan tüm kanalların entegrasyonu ile satış, pazarlama ve müşteri hizmetlerinde müşteri ihtiyaçlarına uygun ürün ve hizmetler üreterek müşteri ilişkilerini iyileştirmektir (İTO, 2004: 6). Müşteri İlişkileri Yönetimi, işletmelerin müşterilerini elde tutmaya, aynı 
zamanda maliyeti düşürmeye, etkileşimi ve etkileşimin değerini arttırmaya, böylece karı maksimize etmeye yönelik bağlantılı yönetimi amaçlar (Burnett, 2001,253).Müşteri ilişkileri yönetiminin amaçlarını şöyle sıralamak mümkündür (Aktepe, Baş ve Tolon, 2009a:4):

- Müşteri ilişkilerini karlı hale getirmek,

- Farklılaşma sağlamak,

- Maliyet minimizasyonu sağlamak,

- İşletmenin verimini artırmak,

- Uyumlu faaliyetler sağlamak,

- Müşteri taleplerini karşılamak

Swift'e göre (2001) ise MíY'in genel amaçları şu şekilde sıralanabilir:

- Müşteri tutma: Sadık ve kârlı müşterilerle, müşterileri ve kanalları işletmeyi büyütmek için elde tutma,

- Müşteri kazanma: Müşterilerden öğrenilen bilgilere dayalı olarak, doğru müşterileri kazanma,

- Müşteri kârlılığ1: Doğru zamanda doğru ürünü doğru müşteriye sunarak, bireysel müşteri marjlarını artırma.

\subsection{Müşsteri Sadakati Kavramı}

Sadakat, müşterinin bir firma ya da marka ile olan ilişkisini devam ettirmek istemesidir. Başka bir ifadeyle, sadakat, müşteri taahhüdüdür. Müşteri sadakati bir işletmeye, ürüne, markaya veya kişiye karsı değişmeyen duygusal ve hissi bir sadakat ve bağlılıktır. Bağlılık, insanın davranışlarını duygusal olarak yönlendirme durumudur (Gödekmerdan ve Deniz, 2010b: 245). Sadık müşteriler, işletmeyle bütünleşmiş ve işletmeyle aralarında duygusal bağ oluşmuş müşterilerdir. Müşteri sadakatinin sağlanması işletmeye müşterilerin tatmin olma oranlarının artması ve müşterilerin devamlılığının sağlanması olarak geri dönmektedir. Ayrıca sadık müşteriler çevrelerindeki insanlara işletme hakkında olumlu tavsiyelerde bulunarak işletmenin adının duyulmasını ve tanınmasını sağlarlar (Avcıkurt ve Köroğlu, 2006: 6). Müşteri sadakati kavramı, işletmenin ürün veya hizmetlerine yönelik olan sadakati ifade edeceği gibi, bir işletmeye olan sadakati de ifade edebilmektedir. Yani sadakat, ürün veya hizmete yönelik olabileceği gibi işletmeye yönelikte olabilmektedir (Bayuk ve Küçük, 2007: 288).

\subsubsection{Müşteri Sadakatinin Tanımı ve Önemi}

Müşteri sadakati, müşterinin belirli bir ürünü veya markayı sürekli satın almasını, ihtiyaç hissettiğinde başka ürün veya marka alternatifini araştırmamasını ifade etmektedir (Aktepe, Baş ve Tolon, 2009b: 20). Oyma'a göre; müşteri sadakati; bir işletmeye ya da markaya olan bağlılık olarak tanımlanmaktadır (Oyman, 2002: 170). Richar'a göre müşteri sadakati; rakip işletmelere ve satın alma kararını değiştirebilecek etkilere rağmen, tercih edilen bir ürün ve hizmeti sürekli olarak satın alarak o ürüne/hizmete ve ya markayı markaya duyulan derin bağlılık olarak tanımlanır 
(Keiningham, vd., 2006: 192). Müşteri sadakatinin önemi; günümüzün getirdiği yoğun rekabet ortamı işletmelerin rekabet avantajı elde edebilmeleri için üstün bir çaba göstermeleri zorunluluğu getirmektedir. İşletmeler sürdürülebilir bir rekabet avantajı elde edebilmek amacıyla müşteri sadakati oluşturmalıdırlar (Özkan ve Yıldız, 2015: 362). Yang ve Peterson'a göre işletmeye sadik olan müşteri yeni bir işletme aramayacak, bilgi edinme ve değerlendirme gibi hususlarda zaman harcamayacaktır (Yang ve Peterson, 2004: 802).

\subsubsection{Müşteri Sadakatini Etkileyen Faktörler}

Müşterilerin bir işletmeye bağlılı̆̆ının artması diğer işletmelere rağmen o işletmeyi tercih etmeleri işletme için önemli bir avantajdır. Çünkü yeni müşteri elde etmenin maliyeti mevcut müşterileri elde tutmanın maliyetinden daha yüksektir6. Bu durumdan da açıkça anlaşılacağı üzere müşteri sadakatinin sağlanması firmalar için son derece önemlidir. Literatürde birçok araştırmacı müşteri sadakatini etkileyen faktörleri incelemişlerdir. Söz konusu faktörler şöyle sıralanabilir (Karakaş, Geyik ve Gökçen, 2014: 161);

Kurumsal imaj; hem imajın kaynağı olan kurum, hem de imajın algılayıcısı durumundaki hedef kitleler için son derece önemlidir. Kurumsal imaj kurumun tüketiciler ile kurduğu iletişimin başlangıcıdır.

Müşteri beklentileri; kişilerin satın aldıkları ürün ya da hizmet ile ilgili ilk deneyimlerinin sonucu olup, kişiden kişiye değişen sübjektif bir kavramdır.

Değiştirme maliyeti; bir tüketicinin bir hizmet sağlayıcıyı başka bir hizmet sağlayıcı ile değiştirdiğinde maruz kalacağı maliyet olarak tanımlanır.

Hizmet kalitesi; müşterinin bir hizmete ilişkin beklentileri ve yararlandığ gerçek hizmet deneyimindeki algısı arasındaki farktan oluşan bir tutum olarak tanimlanmaktadir.

Güven; bir bireyin riskle karşılaşma olasılığına rağmen başka bir gruba inanç duyma isteği olarak tanımlanabilir.

Müşteri memnuniyeti; en genel tanımıyla, müşterinin ürün veya hizmetin arzu, beklenti ve ihtiyaçlarını karşılama yetisinden kaynaklanan genel memnuniyet derecesi, yapılan ürün veya hizmet tercihinin rakiplerine göre yaratabildiği iç huzur ve rahatlık hissidir.

Müşteri şikâyetleri yönetimi; uygulamaları, firmaların müşteri sadakati ve müşteri memnuniyeti sağlamada etkin olarak kullandıkları yöntemlerden biridir.

Fiyat; tüketiciler için ürünün kalitesi ya da faydasının bir ölçütü olarak algilanir. 


\section{MÜŞTERI ILIŞKIILERI YÖNETIMININ MÜŞTERI SADAKATİ ÜZERINE ETKİİ: BANKACILIK SEKTÖRÜ ÜZERİNE BİR ALAN ARAŞTIRMASI}

\subsection{Araştırmanın Amacı, Kapsamı ve Kısıtları}

Araştırmanın temel amacı, elde edilen verilerle müşteri ilişkileri yönetiminin müşteri sadakati üzerine etkisinin araştırılmasıdır. Ayrıca müşteri ilişkileri yönetimi algılamalarının alt faktörlerinin neler olduğunu bulmaya çalışmak ve katılımcıların müşteri ilişkileri yönetimi algılamaları ile demografik özellikleri arasında farklılıkların olup olmadığını belirlemektir. Araştırmanın kapsamını Aydın ilinin Kuşadası ilçesinde bulunan kamu ya da özel bankalarından hizmet alan müşteriler oluşturmaktadır. Araştırma yapılırken zaman ve maliyet gibi kısıtlamalar sebebiyle araştırma alanına coğrafik kısıtlama getirilmiştir.

\subsection{Araştırmanın Yöntemi}

Araştırmada veri toplama yöntemi olarak anket tekniği kullanılmıştır. Anket formu 3 bölümden oluşmaktadır. İlk bölümde katılımcıların demografik özellikleri hakkında bilgiler edinilmeye çalışılmıştır. İkinci bölümde müşterilerin müşteri ilişkileri yönetimi faaliyetlerine ilişkin algılamaları ölçülmeye çalışılmış ve 5'li likert ölçeği kullanılmıştır. Üçüncü bölümde ise müşteri sadakati boyutları ile ilgili ifadeler yer almaktadır ve 5'li likert ölçeği kullanılmıştır. 5'li likert ölçeği 1-Kesinlikle Katılmiyorum, 2-Katılmiyorum, 3-Kararsızım, 4-Katılıyorum ve 5-Kesinlikle Katılıyorum şeklinde değerlendirilmiştir." Likert ölçeği cevaplayıcının bir araştırma ile ilgili yargıları ne derecede tasvip edip etmediğini tespit etmede kullanılır. Cevaplayıcıya yargı hakkında 5 noktalı ve dengeli (eşit aralıklı) bir ölçek verilir"'(Karagöz ve Ekici, 2004: 39). Katılımcılara yöneltilen ifadelerde hangisine ne derecede katıldıklarını öğrenmek için araştırmada 5'li likert ölçeği kullanılmıştır. Müşteri ilişkileri yönetimi ve müşteri sadakati ölçekleri 12 'şer sorudan oluşmaktadır. Sorular literatür taraması yapılarak daha önce yapılmış araştırmalardan yararlanılarak hazırlanmıştır. Anket uygulaması, Aydın ilinin Kuşadası ilçesinde kamu ya da özel bankalarının müşterisi olan kişilere ihtimalsiz örnekleme yöntemlerinden biri olan kolayda örnekleme yöntemine (Nakip, 2006: 211) göre toplam 250 anket dağıtılmış ve bu anketlerden geri dönmeyen, hatalı ve eksik doldurmalardan kaynaklanan sebeplerden dolayı 229 tanesi değerlendirilmeye alınmıştır. Anket uygulaması yapılmadan önce pilot bir uygulama yapılmış ve ölçeğin güvenilirliği ölçülmüştür. Cronbach Alpha katsayısı $(>0,7)$ alınarak güvenilirlik ölçeği belirlenmiştir (Baksi, 2014: 85). Ölçeğin güvenilirlik değeri $\alpha$ : 0.791 olarak bulunmuştur. Anketin geri dönüş oranı \% 92,6 olarak tespit edilmiştir. Elde edilen bu örnek büyüklüğü aynı zamanda ana kütleyi temsil etmeye yetecek örneklem büyüklüğünü kapsamaktadır (Aracı, vd., 2014: 563). Kurulan hipotezleri test etmek için verilere regresyon analizi, korelasyon analizi, çok değişkenli varyans analizi (MANOVA) testleri uygulanmıştır. Ayrıca MIY algılamalarının alt faktörlerini belirlemek için faktör analizi yapılmıştır. 229 katılımcının anketteki sorulara verdikleri cevaplar IBM SPSS (Statistical Package for the Social Sciences) v23 paket programıla analiz edilmiştir. 


\subsection{Araştırmanın Hipotezleri}

Araştırmanın hipotezleri şu şekilde oluşturulmuştur;

- H1: Müşteri ilişkileri yönetimi müşteri sadakati üzerinde olumlu bir etkiye sahiptir.

- $\quad \mathbf{H}_{2}$ : Katılımcıların cinsiyetlerine göre müşteri ilişkileri yönetimi algilamalarında anlamlı bir farklılık vardır.

- H3: Katılımcıların eğitim durumları ile müşteri ilişkileri yönetimi algılamalarında anlamlı bir farklılık vardır.

- H4: Katılımcıların meslekleri ile müşteri ilişkileri yönetimi algılamalarında anlamlı bir farklılık vardır.

- H5: Katılımcıların yaşları ile müşteri ilişkileri yönetimi algılamaları arasında anlamlı bir farklılık vardır.

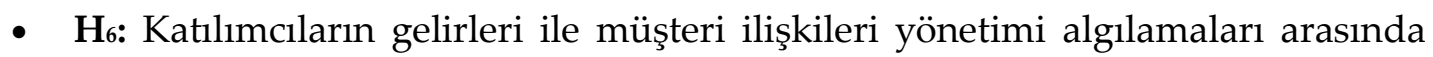
anlamlı bir farklılık vardır.

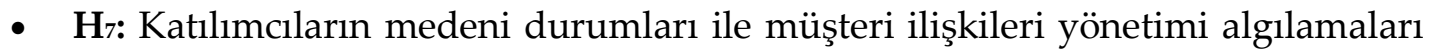
arasinda anlamlı bir farklılık vardır.

- Hs: Katılımcıların bankaları kullanma sıklıkları ile müşteri ilişkileri yönetimi algılamaları arasında anlamlı bir farklılık vardır.

\subsection{Araştırmanın Bulguları}

Katılımcıların demografik özellikleri Tablo 1'de gösterilmiştir. 
Tablo 1. Katılımciların Demografik Özellikleri

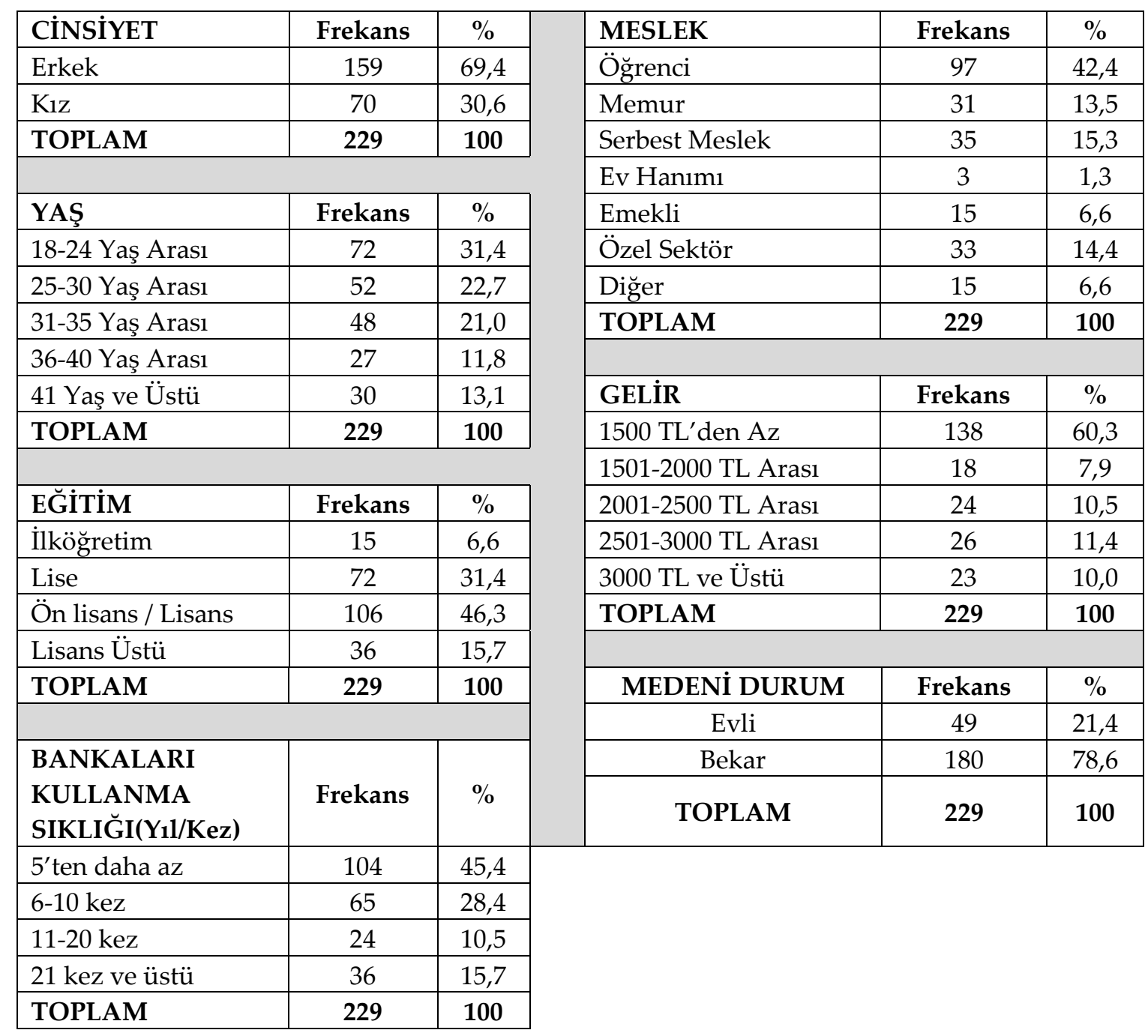

Tablo 1'deki bilgilere bakıldığında araştırmaya katılanların \%69,4'lük kısmının erkek olduğu \% 30,6'sının kadın olduğu görülmektedir. Yaş aralığına bakıldığına bakıldığında en çok 18-24 yaş (\% 31,4) aralığında olduğu ikinci sırada ise 25-30 yaş arası (\% 22,7) olduğu ve en az katılım sağlanan yaş aralığının ise $36-40$ yaş $(\% 11,8)$ arası katılımcılardan oluştuğu görülmektedir. Medeni durumlara bakıldığında \% 78,6'lık oranla katılımcıların bekâr olduğu görülmektedir. Katılımcıların eğitim durumlarının genel olarak yüksek olduğu en çok Ön lisans/ Lisans (\% 46,3) cevabının en az ise ilköğretim $(\% \quad 6,6)$ cevabının verildiği görülmüştür. Meslek gruplarına bakıldığında en çok katılım sağlayanların öğrenciler (\% 42,4) olduğu en az katılım sağlayanların ise ev hanımları (\% 1,3) tarafından olduğu görülmüştür. En yüksek katılımın öğrenciler tarafından sağlanmasındaki temel sebebin çeşitli sınavlar için başvuru yapmak amacıyla bankaları kullanan öğrencilerin anketin yapıldığı dönemde bankalardan hizmet alıyor olması şeklinde düşünülmektedir. Katılımcıların gelir durumlarına bakıldığında en çok yanıt verilen cevabın 1500 TL'den az (\% 60,3) olduğu diğer cevapların ise birbirine çok yakın oldukları görülmektedir. Son olarak 
katılımcıların bankaları kullanma sıklıklarına bakıldığında yılda 5 'ten daha az( $\% 45,4)$ kullananların oranın en yüksek olduğu görülmüştür.

Tablo 2. Müşteri İlişkileri Yönetiminin Müşteri Sadakatine Etkisine İlişkin Basit Doğrusal Regresyon Analizi

\begin{tabular}{|l|c|c|c|c|c|}
\hline Model 1 & \multicolumn{5}{|c|}{ Bağımlı Değişken Müşteri Sadakati } \\
\hline & $\mathrm{B}$ & Std. Sapma & $\beta$ & $\mathrm{T}$ & Anlamlılık \\
\hline Sabit Değer & 1,611 & 0,190 & & 8,486 & 0,000 \\
\hline Müşteri İlişkileri Yönetimi & 0,615 & 0,057 & 0,581 & 10,746 & 0,000 \\
\hline \multicolumn{5}{|c|}{$\mathrm{R}^{2}=0,338$} \\
\hline $\mathrm{F}=0,581$ & Anlamlılık (p)=0,000 \\
\hline
\end{tabular}

Tablo 2 incelendiğinde müşteri ilişkileri yönetiminin müşteri sadakati üzerine etkisinin ölçülmesine yönelik regresyon analizi sonuçlarına göre, korelasyon katsayısı incelendiğinde müşteri ilişkileri yönetimi faaliyetlerinin müşteri sadakatini olumlu ve orta düzeyde $(\mathrm{R}=0,581)$ etkilediği görülmektedir. Müşteri sadakatine ilişkin toplam varyansın \% 33,8'lik kısmının müşteri ilişkileri yönetimi tarafından açıklandığ söylenilebilir. Basit doğrusal denklemimizin $Y=A+B X$ olduğunu göz önüne alındığında $Y=$ Müşteri Sadakati (Bağımlı değişken), $A=1,611$ (Sabit sayı), B= 0,615 (Bağımsız değişkenin katsayısı), X=Müşteri İlişkileri Yönetimi (Bağımsız Değişken) olarak ifade edilebilir. Müşteri ilişkileri yönetiminin müşteri sadakatine etkisini formülleştirecek olursak; Müşteri Sadakati=1,611 + (0,615) Müşteri İlişkileri Yönetimi

Formüle bakıldığında bankacılık alanında faaliyet gösteren işletmelerde müşteri ilişkileri yönetiminin müşteri sadakatini olumlu yönde etkilediği sonucu ortaya çıkmaktadır. İşletmelerin yapacağı 1 birimlik müşteri ilişkileri yönetimi faaliyetlerindeki artış müşteri sadakatini 0,615 oranında olumlu yönde etkileyecektir. Formüle göre eğer işletmeler hiç müşteri ilişkileri yönetimine önem vermeyip bu konu hakkında çalışmalar yapmasa bile sabit sayımız 1,611 olduğu için müşteri sadakati pozitif olacaktır. Bu sonuçlar karşısında $\mathrm{H}_{1}$ hipotezimiz kabul edilmiştir. Müşteri ilişkileri yönetiminin müşteri sadakatine olumlu yönde etkilediğini basit doğrusal regresyon analizi sonucunda ortaya çıkmıştır. Araştırmamızda kullandığımız müşteri ilişkileri yönetimi alt boyutlarının hangilerinin ne derecede etkilediğini öğrenmek için çoklu regresyon analizi ile veriler analiz edilmiştir. 
Tablo 3. Müşteri İlişkileri Yönetiminin Müşteri Sadakatine Etkisine İlişkin Çoklu Doğrusal Regresyon Analizi İle Derinlemesine İncelenmesi

\begin{tabular}{|c|c|c|c|c|c|}
\hline Model 2 & \multicolumn{5}{|c|}{ Bağımlı Değişken Müşteri Sadakati } \\
\hline Bağımsız Değişken & B & Std. Sapma & $\beta$ & $\mathrm{T}$ & Anlamlılık \\
\hline Sabit Değer & 1,891 & 0,289 & & 6,538 & 0,000 \\
\hline *IFADE 1 & 0,073 & 0,037 & 0,133 & 1,964 & 0,041 \\
\hline *IFADE 2 & 0,022 & 0,034 & 0,043 & 0,659 & 0,511 \\
\hline *IFADE 3 & 0,170 & 0,038 & 0,285 & 4,520 & 0,000 \\
\hline *IFADE 4 & 0,078 & 0,050 & 0,078 & 1,555 & 0,121 \\
\hline *IFADE 5 & $-0,041$ & 0,029 & $-0,069$ & $-1,407$ & 0,161 \\
\hline *IFADE 6 & 0,149 & 0,032 & 0,274 & 4,605 & 0,000 \\
\hline$* \dot{\mathrm{IF} A D E} 7$ & 0,104 & 0,033 & 0,188 & 3,118 & 0,002 \\
\hline *IFADE 8 & $-0,073$ & 0,039 & $-0,108$ & $-1,880$ & 0,061 \\
\hline *IFADE 9 & $-0,012$ & 0,033 & 0,021 & 0,353 & 0,725 \\
\hline *IFADE 10 & 0,084 & 0,023 & 0,191 & 3,611 & 0,000 \\
\hline${ }^{*}$ IFADE 11 & $-0,025$ & 0,026 & $-0,058$ &,- 992 & 0,322 \\
\hline *IFADE 12 & 0,142 & 0,032 & 0,279 & 4,491 & 0,000 \\
\hline $\mathrm{R}=0,720$ & $\mathrm{R}^{2}=0,518$ & $\mathrm{~F}=19,330$ & Anlan & $k(p)=0$ & \\
\hline
\end{tabular}

Tablo 3 incelendiğinde müşteri ilişkileri yönetiminin müşteri sadakati üzerinde olumlu yönde etkisinin olduğu görülmektedir. Müşteri ilişkileri yönetimine ilişkin alt boyutların müşteri sadakatini ne ölçüde ve nasıl etkilediği tablo-3'te ki verilerde gösterilmiştir. Basit doğrusal denklemimizi $Y=A+\left(B_{1} X_{1}\right)+\left(B_{2} X_{2}\right)+\left(B_{n} X_{n}\right)$ düzenleyecek olursak müşteri ilişkileri yönetimi alt boyutlarının hangilerinin ne derecede müşteri sadakatini etkilediğini aşağıdaki formülde görülmektedir ( $Y=$ Bağımlı değişken, $A=$ Sabit sayı, $B_{1 \ldots n}=$ Bağımsız değişken katsayıları), $X_{1 \ldots n}=$ Müşteri ilişkileri yönetimi alt boyutları).

Müşteri Sadakati $=1,891+0,073\left(\mathrm{X}_{1}\right)+0,022\left(\mathrm{X}_{2}\right)+0,170\left(\mathrm{X}_{3}\right)+0,078\left(\mathrm{X}_{4}\right)+[-$ $\left.0,041\left(X_{5}\right)\right]+0,149\left(X_{6}\right)+0,104\left(X_{7}\right)+\left[-0,073\left(X_{8}\right)\right]+\left[-0,012\left(X_{9}\right)\right]+0,084\left(X_{10}\right)+\left[-0,025\left(X_{11}\right)\right]+$ $0,142\left(\mathrm{X}_{12}\right)$ şeklinde formülleştirebiliriz $\left(\mathrm{X}_{1,2,3,4,5,6,7,8,9,9,10,11,12}=\right.$ Müşteri İlişkileri Yönetimi alt boyutlarına ilişkin ifadeler). Müşteri sadakatini olumsuz yönde etkileyen(negatif kuvvetli katsayılar) alt boyutların İFADE 5, İFADE 8, İFADE 9, İFADE 11olduğu görülmektedir. İşletmelerin sadık müşterilerini arttırmak ve müşterilerle uzun süreli 
ilişkiler kurarak karlılı̆̆ı arttırmaları için sadakati negatif etkileyen bu alt boyutları dikkate alarak ilişkilerin iyileştirilmesine yönelik somut adımları atmaları gerekmektedir.

Tablo 4. Müşteri İlişkileri Yönetiminin Müşteri Sadakatine Etkisine İlişkin Korelasyon Analizi

\begin{tabular}{|c|c|c|c|}
\hline Model 3 & & $\begin{array}{c}\text { Müşteri İlişkileri } \\
\text { Yönetimi }\end{array}$ & $\begin{array}{l}\text { Müşteri } \\
\text { Sadakati }\end{array}$ \\
\hline \multirow{3}{*}{$\begin{array}{l}\text { Müşteri İlişkileri } \\
\text { Yönetimi }\end{array}$} & Pearson Correlation & \multirow[t]{2}{*}{1} & \multirow{3}{*}{$\begin{array}{r}0,581^{* *} \\
0,000 \\
229\end{array}$} \\
\hline & Sig. (1-tailed) & & \\
\hline & $\mathrm{N}$ & 229 & \\
\hline \multirow{3}{*}{ Müşteri Sadakati } & Pearson Correlation & \multirow{3}{*}{$\begin{array}{r}0,581^{* *} \\
0,000\end{array}$} & \multirow[t]{2}{*}{1} \\
\hline & Sig. (1-tailed) & & \\
\hline & $\mathrm{N}$ & & 229 \\
\hline
\end{tabular}

Tablo 4 incelendiğinde müşteri ilişkileri yönetiminin müşteri sadakatine paralel ve pozitif yönde etki ettiği görülmektedir. Korelasyonu yorumlamada şu sinırlar sıklıkla kullanılmaktadır: Korelasyon katsayısının, mutlak değer olarak, 0,70-1,00 arasında olması "yüksek"; 0,70-0,30 arasında olması, "orta"; 0,30-0,00 olmas1 ise "düşük" düzeyde bir ilişki olarak tanımlanabilir (Büyüköztürk, 2002: 31). Korelasyon katsayının 0,581 oranında olmasından dolayı müşteri ilişkileri yönetiminin müşteri sadakati üzerinde orta düzeyde bir ilişkiye sahip olduğu görülmektedir. İlişkinin yönü daha önceden bilindiği için analizde analiz de 1- tailed (1 kuyruklu) seçeneği seçilmiştir. Korelasyon katsayısı \%99 güven aralığında anlamlı $(p<0,05)$ ve 0,581 olarak bulunmuştur. Bankacılık sektöründe faaliyet gösteren işletmelerin rakiplerini geride bırakmak ve rekabetin yıkıcı etkilerine karşı koyarak varlığını sürdürebilmesi için sadık müşteri portföyünü müşteri ilişkileri yönetimi faaliyetlerine önem vererek arttırmalıdır. Bu sonuçlara bakarak $\mathrm{H}_{1}$ hipotezimizin geçerliliğinin doğruluğu güçlendirilmiştir. 
Tablo 5. Müşteri İlişkileri Yönetimi Algılarının Faktör Analizi Sonuçları

\begin{tabular}{|c|c|c|c|c|c|c|c|}
\hline \multirow[b]{2}{*}{ Bileşenler } & \multicolumn{4}{|c|}{ Başlang1ç Öz değerleri } & \multicolumn{3}{|c|}{$\begin{array}{l}\text { Döndürülen Faktörlerin Karelerinin } \\
\text { Dağılımı }\end{array}$} \\
\hline & Toplam & $\% \mathrm{~V}$ & Taryans & Kümülatif\% & Toplam & \%Varyans & Kümülatif\% \\
\hline 1 & 3,338 & & 30,343 & 30,343 & 2,067 & 18,795 & 18,795 \\
\hline 2 & 1,628 & & 14,803 & 45,146 & 1,901 & 17,281 & 36,077 \\
\hline 3 & 1,202 & & 10,927 & 56,073 & 1,682 & 15,292 & 51,368 \\
\hline 4 & 1,113 & & 10,114 & 66,188 & 1,630 & 14,819 & 66,188 \\
\hline 5 & ,918 & & 8,348 & 74,535 & & & \\
\hline 6 & ,775 & & 7,043 & 81,579 & & & \\
\hline 7 & ,487 & & 4,431 & 86,009 & & & \\
\hline 8 & ,445 & & 4,044 & 90,053 & & & \\
\hline 9 & ,418 & & 3,799 & 93,852 & & & \\
\hline 10 & ,365 & & 3,318 & 97,170 & & & \\
\hline 11 & ,311 & & 2,830 & 100,000 & & & \\
\hline \multicolumn{6}{|c|}{ Kaiser-Meyer-Olkin Örneklem Yeterliliği Ölçüsü } & \multicolumn{2}{|r|}{0,707} \\
\hline \multirow{3}{*}{\multicolumn{3}{|c|}{ Barlett Küresellik Testi }} & \multicolumn{3}{|c|}{ Ki-Kare } & \multicolumn{2}{|c|}{655,591} \\
\hline & & & \multicolumn{3}{|c|}{$\mathrm{df}$} & \multicolumn{2}{|c|}{55} \\
\hline & & & \multicolumn{3}{|c|}{ Sig. } & \multicolumn{2}{|c|}{0,000} \\
\hline
\end{tabular}

Yapılan KMO testi sonucunda ifadelerin faktör analizi yapılmasına uygun olduğu görülmüştür. Müşteri ilişkileri yönetimi algılamalarına yönelik yapılan faktör analizi sonucunda Tablo 5'te görüldügüu üzere 4 alt faktörün oluşturulmuştur. İfadeler arasından bir tanesinin (IFADE9) bütün faktörlere yüksek derecede katkı sağladığı görülmüş ve analiz yapılırken analize dâhil edilmemiştir. Faktörler oluşturulurken varyansı 1'den büyük olanlar değerlendirilmeye alınarak belirlenmiştir. Belirlenen 4 faktörün toplam varyansın \%66'sını açıkladığı saptanmıştır.

Tablo 6. Müşteri İlişkileri Yönetimi Algılarının Döndürülmüş Faktörler Matrisi

\begin{tabular}{|l|r|r|r|r|}
\hline \multirow{2}{*}{\multicolumn{1}{|c|}{ İFADELER }} & \multicolumn{4}{c|}{ Faktörler } \\
\cline { 2 - 5 } & \multicolumn{1}{c|}{1} & \multicolumn{1}{c|}{2} & \multicolumn{1}{c|}{3} & \multicolumn{1}{c|}{4} \\
\hline İFADE 1 & 0,127 & $\mathbf{0 , 8 8 6}$ & 0,060 & $-0,107$ \\
\hline İFADE 2 & 0,090 & $\mathbf{0 , 7 8 5}$ & 0,301 & 0,085 \\
\hline İFADE 3 & 0,444 & $\mathbf{0 , 6 0 3}$ & 0,123 & $-0,062$ \\
\hline İFADE 4 & $-0,033$ & 0,021 & 0,035 & $\mathbf{0 , 8 8 8}$ \\
\hline İFADE 5 & 0,009 & $-0,080$ & $-0,022$ & $\mathbf{0 , 8 7 1}$ \\
\hline İFADE 6 & $\mathbf{0 , 5 3 2}$ & 0,018 & 0,326 & $-0,035$ \\
\hline İFADE 7 & $\mathbf{0 , 7 8 2}$ & 0,206 & $-0,121$ & $-0,139$ \\
\hline İFADE 8 & $\mathbf{0 , 7 3 9}$ & 0,125 & 0,038 & 0,128 \\
\hline İFADE 10 & $-0,095$ & 0,131 & $\mathbf{0 , 6 1 5}$ & 0,109 \\
\hline İFADE 11 & 0,135 & 0,189 & $\mathbf{0 , 8 1 0}$ & $-0,096$ \\
\hline İFADE 12 & 0,316 & 0,136 & $\mathbf{0 , 6 1 3}$ & $-0,052$ \\
\hline
\end{tabular}


Faktörler için anlamlı gruplandırmalar sağlamak adına varimax döndürme yöntemi kullanılarak grup ifadeleri belirlenmiştir. Tablo-6'daki veriler dikkate alındığında bu gruplandırmalar şöyle isimlendirilebilir;

Faktör 1: İfade 6, 7 ve 8; Hizmet Sunumu

Faktör 2: İfade 1, 2 ve 3; Kaliteli ve Faydalı Hizmet Anlayışı

Faktör 3: İfade 10, 11 ve 12; Beklentilere Karşılık Verme

Faktör 4: İfade 4 ve 5; Hizmet Farkındalığı Sağlama

Tablo 7. Hizmet Sunumunun Alt Boyutlarıyla Korelasyon Analizi Sonuçları

\begin{tabular}{|c|c|c|c|c|c|}
\hline FAKTÖR & IFADELER & IFADE 6 & IFFDE 7 & IFADE 8 & $\begin{array}{c}\text { Hizmet } \\
\text { Sunumu }\end{array}$ \\
\hline \multirow{2}{*}{$\begin{array}{c}\text { Hizmet } \\
\text { Sunumu }\end{array}$} & İFADE 6 & 1 & & & \\
\cline { 2 - 6 } & IFADE 7 & 0,494 & 1 & & \\
\cline { 2 - 6 } & IFADE 8 & 0,524 & 0,426 & 1 & \\
\hline & Hizmet Sunumu & 0,714 & 0,788 & 0,704 & 1 \\
\hline
\end{tabular}

Tablo 7'de Hizmet Sunumu faktörünün alt boyutlarıyla korelasyon değerleri verilmiştir. Birbirleri arasındaki korelasyon değerlerinin yüksek sayılacak rakamlarda olduğu söylenebilir.

Tablo 8. Kaliteli ve Faydalı Hizmet Anlayışının Alt Boyutlarıyla Korelasyon Analizi Sonuçları

\begin{tabular}{|c|c|c|c|c|c|}
\hline \multirow{2}{*}{ FAKTÖR } & İFADELER & İFADE 1 & İFADE 2 & İFADE 3 & $\begin{array}{c}\text { Kaliteli ve } \\
\text { Faydalı } \\
\text { Hizmet } \\
\text { Anlayışının }\end{array}$ \\
\hline $\begin{array}{c}\text { Kaliteli ve Faydalı } \\
\text { Hizmet } \\
\text { Anlayışının }\end{array}$ & İFADE 1 & 1 & & & \\
\cline { 2 - 6 } & İFADE 2 & 0,597 & 1 & & \\
\hline \multicolumn{2}{|c|}{$\begin{array}{c}\text { Kaliteli ve Faydalı } \\
\text { Hizmet Anlayışının }\end{array}$} & 0,857 & 0,829 & 0,750 & 1 \\
\hline
\end{tabular}

Tablo 9. Beklentilere Karşılık Vermenin Alt Boyutlarıyla Korelasyon Analizi Sonuçları

\begin{tabular}{|c|c|c|c|c|c|}
\hline \multirow{2}{*}{ FAKTÖR } & İFADELER & İFADE 10 & IFADE 11 & İFADE 12 & $\begin{array}{c}\text { Beklentilere } \\
\text { Karş1lık } \\
\text { Verme }\end{array}$ \\
\hline \multirow{2}{*}{$\begin{array}{c}\text { Beklentilere } \\
\text { Karşılık Verme }\end{array}$} & IFADE 10 & 1 & & & \\
\cline { 2 - 6 } & IFADE 11 & 0,318 & 1 & & \\
\cline { 2 - 6 } & IFADE 12 & 0,153 & 0,413 & 1 & 1 \\
\hline
\end{tabular}


Tablo 10. Hizmet Farkındalığı Sağlamanın Alt Boyutlarıyla Korelasyon Analizi Sonuçları

\begin{tabular}{|c|c|c|c|c|}
\hline \multirow{2}{*}{ FAKTÖR } & IFADELER & IFADE 4 & IFADE 5 & $\begin{array}{c}\text { Hizmet } \\
\text { Farkındalı̆̆ } \\
\text { Sağlama }\end{array}$ \\
\hline $\begin{array}{c}\text { Hizmet Farkındalı̆̆1 } \\
\text { Sağlama }\end{array}$ & İFADE 4 & 1 & & \\
\cline { 2 - 5 } & IFADE 5 & 0,573 & 1 & \\
\hline \multicolumn{2}{|c|}{$\begin{array}{c}\text { Hizmet Farkındalığı } \\
\text { Sağlama }\end{array}$} & 0,799 & 0,951 & 1 \\
\hline
\end{tabular}

Tablo 7, Tablo 8, Tablo 9 ve Tablo 10' da elde edilen müşteri ilişkileri yönetimi algılamaları alt faktörlerinin kendilerini oluşturan ifadelerle ilgili korelasyon analizleri yapılmış ve ayrıntılı bilgiler tablolarda gösterilmiştir. Tablolar incelendiğinde faktörlerin hepsinin yüksek korelasyon değerleri aldığı görülmektedir.

Tablo 11. Müşteri İlişkileri Yönetimi Algılamalarının Alt Faktörlerinin Korelasyon Analizi Sonuçları

\begin{tabular}{|c|c|c|c|c|}
\hline Faktörler & $\begin{array}{c}\text { Hizmet } \\
\text { Sunumu }\end{array}$ & $\begin{array}{c}\text { Kaliteli ve } \\
\text { Faydalı Hizmet } \\
\text { Anlayışının }\end{array}$ & $\begin{array}{c}\text { Beklentilere } \\
\text { Karşılık } \\
\text { Verme }\end{array}$ & $\begin{array}{c}\text { Hizmet } \\
\text { Farkındalı̆̆ı } \\
\text { Sağlama }\end{array}$ \\
\hline Hizmet Sunumu & 1 & & & \\
\hline $\begin{array}{c}\text { Kaliteli ve Faydalı } \\
\text { Hizmet Anlayışının }\end{array}$ & 0,430 & 1 & 1 & \\
\hline $\begin{array}{c}\text { Beklentilere Karşılık } \\
\text { Verme }\end{array}$ & 0,433 & 0,419 & $-0,028$ & 1 \\
\hline $\begin{array}{c}\text { Hizmet Farkındalığı } \\
\text { Sağlama }\end{array}$ & $-0,049$ & $-0,076$ & & \\
\hline
\end{tabular}

Müşteri ilişkileri yönetimi algılamalarının alt faktörlerinin korelasyon değerlerini gösteren Tablo 11 incelendiğinde "Hizmet Farkındalığı Sağlama" faktörünün diğer faktörlerle arasında negatif ilişkinin olduğu görülmektedir. Diğer faktörlerin ise orta düzeyde korelasyon değeri aldığı söylenebilir.

Tablo 12. Müşteri İlişkileri Yönetimi Algılamaları Alt Faktörlerinin Müşteri Sadakatine Etki Gücünün Belirlenmesi

\begin{tabular}{|l|c|c|c|c|c|}
\hline & \multicolumn{5}{|c|}{ Bağımlı Değişken Müşteri Sadakati } \\
\hline & B & Std. Sapma & $\beta$ & $\mathrm{T}$ & Anlamlılık \\
\hline Sabit Değer & 1,682 & 0,234 & & 7,200 & 0,000 \\
\hline Hizmet Sunumu & 0,297 & 0,048 & 0,375 & 6,135 & 0,000 \\
\hline $\begin{array}{l}\text { Kaliteli ve Faydalı Hizmet } \\
\text { Anlayışının }\end{array}$ & 0,083 & 0,041 & 0,122 & 2,002 & 0,047 \\
\hline Beklentilere Karşılık Verme & 0,171 & 0,038 & 0,272 & 4,489 & 0,000 \\
\hline Hizmet Farkındalığ Sağlama & 0,054 & 0,039 & 0,072 & 1,378 & 0,170 \\
\hline \multicolumn{5}{|c|}{$\mathrm{R}=0,620$} & Anlamlılık $(\mathrm{p})=0,000$ \\
\hline \multicolumn{7}{|c|}{$\mathrm{F}=35,010$} \\
\hline
\end{tabular}


Faktör analizi sonucunda elde edilen faktörlerin müşteri sadakatine etkileri regresyon analizi yapılarak incelendiğinde faktörlerin müşteri sadakatini etkileme dereceleri Tablo 12'de görüldügü gibi çıkmıştır. En çok etkiye sahip olan faktörün hizmet sunumu olduğu görülmektedir. Toplam varyansın \%39'luk kısmının belirlenen faktörler tarafından açıklandığı söylenilebilir $\left(R^{2}=0,385\right)$.

Tablo 13. Katılımcıların Cinsiyetlerine Göre Müşteri İlişkileri Yönetimi Algılamalarının Karşılaştırılması

\begin{tabular}{|c|c|c|c|c|c|}
\hline & \multirow{2}{*}{ İFADELER } & \multicolumn{2}{|c|}{ Ortalamalar } & \multirow{2}{*}{$\begin{array}{c}F \\
\text { Değeri }\end{array}$} & \multirow{2}{*}{ Sig.(p) } \\
\hline & & Erkek & $\mathrm{K}_{1 \mathrm{z}}$ & & \\
\hline İFADE 1 & $\begin{array}{l}\text { Kullandığım banka yönetimi ve personeli } \\
\text { müşteri memnuniyetine önem vermektedir. }\end{array}$ & 3,188 & 3,271 & 9,519 & 0,577 \\
\hline İFADE 2 & $\begin{array}{l}\text { Kullandığım banka, ürün ve hizmet fiyatları } \\
\text { makuldür. }\end{array}$ & 3,018 & 2,900 & 0,413 & 0,439 \\
\hline İFADE 3 & $\begin{array}{l}\text { Kullandığım bankanın ürün ve hizmet } \\
\text { kalitesi yüksektir. }\end{array}$ & 3,245 & 3,185 & 2,388 & 0,660 \\
\hline İFADE 4 & $\begin{array}{l}\text { Kullandı̆̆ım bankanın reklamlarını sürekli } \\
\text { görüyorum. }\end{array}$ & 4,509 & 4,214 & 0,624 & 0,000 \\
\hline İFADE 5 & $\begin{array}{l}\text { Kullandığım bankanın kampanya ve } \\
\text { indirimlerinden haberdar edilirim. }\end{array}$ & 4,150 & 4,042 & 6,608 & 0,427 \\
\hline İFADE 6 & $\begin{array}{l}\text { Kullandığım banka, diğer bankalardan } \\
\text { farklı hizmetler sunuyor. }\end{array}$ & 2,792 & 2,528 & 0,053 & 0,076 \\
\hline İFADE 7 & $\begin{array}{l}\text { Kullandığım bankanın personeli } \\
\text { profesyoneldir ve bilgi birikimleri yeterli } \\
\text { düzeydedir. }\end{array}$ & 3,320 & 3,414 & 0,103 & 0,525 \\
\hline İFADE 8 & $\begin{array}{l}\text { Kullandığım banka personeli güler yüzlü ve } \\
\text { ilgilidir. }\end{array}$ & 3,547 & 3,357 & 0,356 & 0,113 \\
\hline İFADE 9 & $\begin{array}{l}\text { Kullandığım bankada, önerilerim dikkate } \\
\text { alınır. }\end{array}$ & 2,867 & 2,957 & 0,022 & 0,543 \\
\hline $\begin{array}{c}\text { İFADE } \\
10 \\
\end{array}$ & $\begin{array}{l}\text { Kullandığım bankada, özel isteklerim } \\
\text { karşılanır. }\end{array}$ & 3,509 & 3,671 & 0,069 & 0,381 \\
\hline $\begin{array}{l}\text { İFADE } \\
11\end{array}$ & $\begin{array}{l}\text { Kullandığım banka müşterilerine özel } \\
\text { günleri için beklenmedik bir anda } \\
\text { beklenmedik sürprizler yapabilir. }\end{array}$ & 2,547 & 2,128 & 8,027 & 0,023 \\
\hline $\begin{array}{c}\text { İFADE } \\
12 \\
\end{array}$ & $\begin{array}{l}\text { Kullandığım banka, müşteri ihtiyaçlarını } \\
\text { anlar ve karşılar. }\end{array}$ & 2,905 & 2,814 & 0,008 & 0,567 \\
\hline \multicolumn{2}{|r|}{ GENEL ORTALAMALAR } & 3,30 & 3,20 & & \\
\hline Hote & g's T Testi F Değeri=2,469 & $s i=16$ & alamlı & Düzeyi & 0,005 \\
\hline
\end{tabular}

Katılımcıların cinsiyet verilerine bakıldığında 70 kız, 159 erkek katılımcının olduğu görülmektedir. Katılımcıların cinsiyetlerine göre müşteri ilişkileri yönetimi algılamalarının karşılaştırılması için elde edilen verilere çoklu varyans analizi (MANOVA) yapılmıştır. Tablo 13 incelendiğinde katılımcıların cinsiyetleriyle müşteri ilişkileri yönetimi algılamalarının arasında genel olarak anlamlı bir farkın olduğu 
görülmüştür (Hotelling's T Testi Anlamlılık Düzeyi =0,005 < 0,05). Cinsiyetlere göre müşteri ilişkileri yönetimi ile ilgi on iki ifadenin genel ortalamaları birbirine yakın çıktığ1 görülmüştür (Erkek: 3,30 Kı: 3,20). Tabloda müşteri ilişkileri yönetimi ifadelerinden 2 tanesinin farklı algılandığ görülmüş ve farklı algılanan ifadeler Tablo 13 'te koyu rakamlarla belirtilmiştir. Erkek ve kadınların müşteri ilişkileri yönetimi ile ilgili ifadelere verdikleri cevaplar kararsızım seçeneği ile katılıyorum seçeneği arasında fakat kararsızım seçeneğine daha yakın olduğu görülmektedir. Katılımcıların cinsiyetlerine göre müşteri ilişkileri yönetimi algilamalarının belirsizlik düzeyinde olması onların bu konuyla ilgili bilgi ve tatmin düzeylerinin karmaşık olmasından dolayı kaynaklandığı söylenebilir. Genel olarak sonuçlara bakıldığında $\mathrm{H}_{2}$ hipotezimiz kabul edilmiştir.

Tablo 14. Katılımcıların Eğitim Durumlarına Göre Müşteri İlişkileri Yönetimi Algılamalarının Karşılaştırılması

\begin{tabular}{|c|c|c|c|c|c|c|c|}
\hline & \multirow{2}{*}{ İFADELER } & \multicolumn{4}{|c|}{ Ortalamalar } & \multirow{2}{*}{$\mathbf{F}$} & \multirow{2}{*}{$\operatorname{Sig}(p)$} \\
\hline & & $1^{*}$ & $2^{*}$ & $3^{*}$ & $4^{*}$ & & \\
\hline $\begin{array}{l}\text { İFADE } \\
\quad 1\end{array}$ & $\begin{array}{l}\text { Kullandığım banka yönetimi ve } \\
\text { personeli müşteri memnuniyetine } \\
\text { önem vermektedir. }\end{array}$ & 2,80 & 3,12 & 3,32 & 2,25 & 1,38 & 0,248 \\
\hline $\begin{array}{c}\text { IFADE } \\
2 \\
\end{array}$ & $\begin{array}{l}\text { Kullandığım banka, ürün ve hizmet } \\
\text { fiyatları makuldür. }\end{array}$ & 3,00 & 2,87 & 3,10 & 2,83 & 0,93 & 0,425 \\
\hline $\begin{array}{c}\text { IFADE } \\
3 \\
\end{array}$ & $\begin{array}{l}\text { Kullandığım bankanın ürün ve } \\
\text { hizmet kalitesi yüksektir. }\end{array}$ & 3,00 & 3,29 & 3,26 & 3,08 & 0,73 & 0,532 \\
\hline $\begin{array}{c}\text { IFADE } \\
4\end{array}$ & $\begin{array}{l}\text { Kullandığım bankanın reklamlarını } \\
\text { sürekli görüyorum. }\end{array}$ & 4,80 & 4,62 & 4,25 & 3,33 & 9,58 & 0,000 \\
\hline $\begin{array}{l}\text { İFADE } \\
\quad 5\end{array}$ & $\begin{array}{l}\text { Kullandığım bankanın kampanya ve } \\
\text { indirimlerinden haberdar edilirim. }\end{array}$ & 4,60 & 4,12 & 4,00 & 3,25 & 2,11 & 0,099 \\
\hline $\begin{array}{c}\text { İFADE } \\
6 \\
\end{array}$ & $\begin{array}{l}\text { Kullandığım banka, diğer } \\
\text { bankalardan farklı hizmetler sunuyor. }\end{array}$ & 2,80 & 2,58 & 2,74 & 2,83 & 0,60 & 0,613 \\
\hline $\begin{array}{l}\text { İFADE } \\
\quad 7\end{array}$ & $\begin{array}{l}\text { Kullandığım bankanın personeli } \\
\text { profesyoneldir ve bilgi birikimleri } \\
\text { yeterli düzeydedir. }\end{array}$ & 3,00 & 3,29 & 3,64 & 2,75 & 8,42 & 0,000 \\
\hline $\begin{array}{l}\text { IFADE } \\
\quad 8\end{array}$ & $\begin{array}{l}\text { Kullandığım banka personeli güler } \\
\text { yüzlü ve ilgilidir. }\end{array}$ & 3,00 & 3,45 & 3,63 & 3,33 & 3,29 & 0,021 \\
\hline $\begin{array}{l}\text { İFADE } \\
9 \\
\end{array}$ & $\begin{array}{l}\text { Kullandığım bankada, önerilerim } \\
\text { dikkate alınır. }\end{array}$ & 2,40 & 2,83 & 2,94 & 3,08 & 1,77 & 0,154 \\
\hline $\begin{array}{c}\dot{\mathrm{I} F A D E} \\
10\end{array}$ & $\begin{array}{l}\text { Kullandığım bankada, özel isteklerim } \\
\text { karşılanır. }\end{array}$ & 3,60 & 3,66 & 3,47 & 3,18 & 0,33 & 0,798 \\
\hline
\end{tabular}


Tablo 14. Katılımcıların Eğitim Durumlarına Göre Müşteri İlişkileri Yönetimi Algılamalarının Karşılaştırılması (Devamı)

\begin{tabular}{|c|c|c|c|c|c|c|c|}
\hline & \multirow{2}{*}{ İFADELER } & \multicolumn{4}{|c|}{ Ortalamalar } & \multirow{2}{*}{$\mathbf{F}$} & \multirow{2}{*}{$\operatorname{Sig}(p)$} \\
\hline & & $1^{*}$ & $2^{*}$ & $3^{*}$ & $4^{*}$ & & \\
\hline $\begin{array}{l}\text { İFADE } \\
11\end{array}$ & $\begin{array}{l}\text { Kullandığım banka müşterilerine özel } \\
\text { günleri için beklenmedik bir anda } \\
\text { beklenmedik sürprizler yapabilir. }\end{array}$ & 1,60 & 2,25 & 2,31 & 3,11 & 9,98 & 0,000 \\
\hline $\begin{array}{l}\text { IFADE } \\
12\end{array}$ & $\begin{array}{l}\text { Kullandı̆̆ım banka, müşteri } \\
\text { ihtiyaçlarını anlar ve karşılar. }\end{array}$ & 3,20 & 2,75 & 2,87 & 3,00 & 0,88 & 0,450 \\
\hline & GENEL ORTALAMALAR & 3,15 & 3,24 & 3,29 & 3,01 & & \\
\hline
\end{tabular}

Tablo 14'te katılımcıların eğitim düzeyleri ile müşteri ilişkileri yönetimi algılamaları çok yönlü varyans analizi (MANOVA) ile test edilmiş ve eğitim düzeyleriyle müşteri ilişkileri yönetimi algılamaları arasında anlamlı bir farkın olduğu görülmüştür (Hotelling's T Testi F Değeri=4,533 Serbestlik Derecesi=36 Anlamlılık Düzeyi=0,000). Eğitim düzeylerinin genel ortalamalarına bakıldığında en düşük ortalamaya sahip eğitim düzeyinin lisansüstü (3.01) olduğu görülmektedir. Lisansüstü eğitime sahip olanların tatmin düzeylerinin yüksek olmasında dolayı en düşük ortalamaya sahip oldukları söylenilebilir. Bunun yanında araştırmacı ve bilinçli tüketici olmaları veya aldıkları hizmetler ile ilgili bilgilerinin fazla olması onların müşteri ilişkileri yönetimi algılarının düşük ortalamaya sahip olduklarını açıklayabilir. Ortalamasının en yüksek olduğu eğitim düzeyinin ise ön lisans/lisans $(3,29)$ eğitim düzeyinde olanların olduğu görülmektedir. Ön lisans/lisans eğitim durumuna sahip olanların müşteri ilişkileri yönetimi algılamalarının yüksek olmasının nedeni olarak çoğunun kullandığı bankayla sadece maaş müşterisi olması söylenebilir. Yani bankayla ilişkilerinin temel sebebi olarak çalıştıkları işletmelerde aldıkları maaşın işletmenin anlaşmalı olduğu banka tarafında verilmesi bu yüzdende çalışanların sadece bankalarla maaş müşterisi olarak ilişki kurması şeklinde yorumlanabilir. Genel olarak sonuçlara bakıldığında $\mathrm{H}_{3}$ hipotezimiz kabul edilmiştir. 
Tablo 15. Katılımcıların Mesleklerine Göre Müşteri İlişkileri Yönetimi Algılamalarının Karşılaştırılması

\begin{tabular}{|c|c|c|c|c|c|c|c|c|c|}
\hline \multirow{2}{*}{ İFADELER } & \multicolumn{7}{|c|}{ Ortalamalar } & \multirow{2}{*}{$\mathbf{F}$} & \multirow{2}{*}{$\operatorname{Sig}(p)$} \\
\hline & $1^{*}$ & $2^{*}$ & $3^{*}$ & $4^{*}$ & $5^{*}$ & $6^{*}$ & $7^{*}$ & & \\
\hline $\begin{array}{l}\text { İFADE 1-Kullandiğım banka } \\
\text { yönetimi ve personeli } \\
\text { müşteri memnuniyetine } \\
\text { önem vermektedir. }\end{array}$ & 3,17 & 3,80 & 3,37 & 2,20 & 2,20 & 3,18 & 3,20 & 5,57 & 0,000 \\
\hline $\begin{array}{l}\text { İFADE 2-Kullandığım } \\
\text { banka, ürün ve hizmet } \\
\text { fiyatları makuldür. }\end{array}$ & 3,10 & 3,54 & 3,31 & 2,09 & 1,60 & 2,36 & 3,20 & 9,12 & 0,000 \\
\hline $\begin{array}{l}\text { İFADE 3-Kullandığım } \\
\text { bankanın ürün ve hizmet } \\
\text { kalitesi yüksektir. }\end{array}$ & 3,38 & 3,32 & 3,31 & 2,50 & 2,00 & 3,36 & 3,00 & 6,79 & 0,000 \\
\hline $\begin{array}{l}\text { İFADE 4-Kullandığım } \\
\text { bankanın reklamlarını } \\
\text { sürekli görüyorum. }\end{array}$ & 4,54 & 4,29 & 4,54 & 5,00 & 4,60 & 4,00 & 4,20 & 6,24 & 0,000 \\
\hline $\begin{array}{l}\text { İFADE 5-Kullandığım } \\
\text { bankanın kampanya ve } \\
\text { indirimlerinden haberdar }\end{array}$ & 4,16 & 4,19 & 4,22 & 2,05 & 4,20 & 4,27 & 3,40 & 4,68 & 0,000 \\
\hline $\begin{array}{l}\text { İFADE 6-Kullandığım } \\
\text { banka, diğer bankalardan } \\
\text { farklı hizmetler sunuyor. }\end{array}$ & 2,83 & 2,70 & 2,68 & 2,00 & 2,00 & 2,81 & 2,60 & 1,77 & 0,107 \\
\hline $\begin{array}{l}\text { İFADE 7-Kullandığım } \\
\text { bankanın personeli } \\
\text { profesyoneldir ve bilgi } \\
\text { birikimleri yeterli } \\
\text { düzeydedir. }\end{array}$ & 3,37 & 3,06 & 3,25 & 2,15 & 2,60 & 3,90 & 3,80 & 5,36 & 0,000 \\
\hline $\begin{array}{l}\text { İFADE 8-Kullandığım banka } \\
\text { personeli güler yüzlü ve } \\
\text { ilgilidir. }\end{array}$ & 3,50 & 3,70 & 3,65 & 2,45 & 2,60 & 3,45 & 3,80 & 6,10 & 0,000 \\
\hline $\begin{array}{l}\text { İFADE 9-Kullandığım } \\
\text { bankada, önerilerim dikkate } \\
\text { alınır. }\end{array}$ & 2,74 & 2,90 & 2,94 & 2,03 & 2,80 & 3,45 & 2,80 & 2,56 & 0,021 \\
\hline $\begin{array}{l}\text { İFADE 10-Kullandığım } \\
\text { bankada, özel isteklerim } \\
\text { karşılanır. }\end{array}$ & 3,62 & 3,25 & 4,17 & 2,29 & 3,40 & 3,18 & 3,60 & 3,07 & 0,007 \\
\hline
\end{tabular}


Tablo 15. Katılımcıların Mesleklerine Göre Müşteri İlişkileri Yönetimi Algılamalarının Karşılaştırılması (Devamı)

\begin{tabular}{|c|c|c|c|c|c|c|c|c|c|}
\hline \multirow{2}{*}{ İFADELER } & \multicolumn{7}{|c|}{ Ortalamalar } & \multirow{2}{*}{ F } & \multirow{2}{*}{$\operatorname{Sig}(p)$} \\
\hline & $1^{*}$ & 2* & $3 *$ & $4^{*}$ & $5^{*}$ & $6^{*}$ & $7^{*}$ & & \\
\hline $\begin{array}{l}\text { İFADE 11-Kullandığım } \\
\text { banka müşterilerine özel } \\
\text { günleri için beklenmedik bir } \\
\text { anda beklenmedik sürprizler } \\
\text { yapabilir. }\end{array}$ & 2,57 & 2,09 & 2,88 & 2,25 & 1,40 & 2,09 & 2,80 & 3,76 & 0,001 \\
\hline $\begin{array}{l}\text { İFADE 12- Kullandığım } \\
\text { banka, müş̧teri ihtiyaçlarını } \\
\text { anlar ve karşılar. }\end{array}$ & 2,98 & 3,45 & 2,77 & 2,10 & 1,80 & 2,45 & 3,40 & 6,43 & 0,000 \\
\hline GENEL ORTALAMALAR & 3,33 & 3,35 & 3,42 & 2,42 & 2,60 & 3,20 & 3,31 & & \\
\hline $\begin{array}{l}\text { Hotelling's T Testi F Değ } \\
\text { Açıklama: } 1^{*}=\text { Öğrenci, }\end{array}$ & ri $=4,9$ & $\begin{array}{l}5 \text { S } \\
\text { hur, } \\
\text { Sekt }\end{array}$ & estli & Dere & $\begin{array}{l}\text { si }=72 \\
\text { lek, } 4 \\
=\text { Diğe }\end{array}$ & Anl & & üzeyi & $\begin{array}{l}\text {,000 } \\
\text { kli, }\end{array}$ \\
\hline
\end{tabular}

Tablo 15'te katılımcıların meslekleri ile müşteri ilişkileri yönetimi algılamaları çok yönlü varyans analizi (MANOVA) ile test edilmiş ve meslekleri ile müşteri ilişkileri yönetimi algılamaları arasında anlamlı bir farkın olduğu görülmüştür (Hotelling's T Testi F Değeri=4,905; Serbestlik Derecesi=72; Anlamlılık Düzeyi=0,000). Müşteri ilişkileri yönetimi ile ilgili ifadelere verilen cevapların genel ortalamasına bakıldığında en yüksek ortalamaya sahip olanın serbest meslek $(3,42)$ grubunda olduğu, en düşük ortalamaya sahip olanin ise emekli $(2,60)$ grubunda olduğu görülmüştür. Diğer meslek gruplarının ise 3.00 ile 3.50 arasında ortalamalara sahip oldukları görülmektedir. Meslek grupları tarafından anlamlı bir şekilde farklılaşan ifadelerin anlamlılık düzeyleri tabloda koyu rakamlarla gösterilmiştir. Cevaplar arasında istatistiksel olarak farklılaşmayanın "Kullandığım banka, diğer bankalardan farklı hizmetler sunuyor." İfadesi olduğu görülmüştür.

Tablo 16. Katılımcıların yaş, gelir, medeni durum ve bankaları kullanma sıklıkları ile müşteri ilişkileri yönetimi algılamalarının karşılaştııılması sonucu elde edilen Hotelling's Trace Test sonuçları

\begin{tabular}{|l|c|c|c|}
\hline \multirow{2}{*}{ Değişkenler } & \multicolumn{3}{|c|}{ Hotelling's Trace Test Değerleri } \\
\cline { 2 - 4 } & F Değeri & Serbestlik Derecesi & Sig.(p) \\
\hline Yaş & 1,186 & 16 & 0,088 \\
\hline Gelir & 1,569 & 16 & 0,102 \\
\hline Medeni Durum & 1,053 & 32 & 0,069 \\
\hline $\begin{array}{l}\text { Bankaları Kullanma } \\
\text { Siklıkları }\end{array}$ & 1,235 & 16 & 0,096 \\
\hline
\end{tabular}

Tablo 16' da görüldüğü gibi yaş, gelir, medeni durum ve bankaları kullanma sıklığı değişkenlerine çok yönlü varyans analizi yapılmış ve Hotelling's $T$ Testi 
anlamlılık düzeylerinin 0.05 'ten büyük olması nedeniyle $\mathrm{H}_{5}, \mathrm{H}_{6}, \mathrm{H}_{7}$ ve $\mathrm{H}_{8}$ hipotezleri reddedilmiştir.

\section{SONUÇ VE ÖNERILER}

Rekabet ortamının ülke sınırlarını aşarak geniş coğrafyalara taşınması, işletmelerin yeni müşteri ilişkileri yönetimi stratejileri geliştirmesi ve müşterilerin ihtiyaçlarının en iyi şekilde karşılaması zorunluluğunu ortaya çıkarmıştır. Hatta günümüz koşullarında işletmelerin rakipleri karşısında rekabet avantajı elde edebilmesi için müşterilerin istek ve ihtiyaçlarını önceden tahmin edip onlara yenilik yaratan bir işletme anlayışıyla şaşırtması ve müşteriler üzerinde olumlu bir imaj bırakması gerekmektedir.

Daha önce yapılan çalışmaların birçoğunda olduğu gibi bu araştırmada da müşteri ilişkileri yönetiminin müşteri sadakati üzerinde olumlu yönde etkiye sahip olduğu görülmüştür. Müşteri ilişkileri yönetimi algılamalarının alt faktörleri arasında en çok öneme sahip olan faktörün Hizmet Sunumu faktörü olduğu görülmüştür. Katılımcıların, sadakati etkileyen en önemli öğelerden güven, memnuniyet vd. öğelerin yerine hizmet sunanlardan güler yüzlü, yeterli bilgi birikim sahibi personelin kendilerine hizmet etmesi beklentisi içerisinde olduğu saptanmıştır. Katılımcıların, kendi özel istek ve önerilerinin hizmet sağlayıcıları tarafından dikkate alınması gerektiği konusunda hem fikir oldukları söylenebilir. Bu özel istek ve önerilerin karşılıksız kalmayıp olumlu geri dönüşlerin sağlanması gerektiği kanaatinde oldukları görülmektedir. Araştırmada seçilen örneklem alanında coğrafik kısıtlama yapıldığından dolayı sonuç olarak ortaya koyulan varsayımlarla genelleme yapılamayacağı ön görülmektedir. Ancak literatürde bulunan birçok araştırmada da görüldügü gibi müşteri ilişkileri yönetiminin müşteri sadakatini yakalamada önemli bir kavram olduğu reddedilemez bir gerçektir. siralanabilir;

Araştırma kapsamında elde edilen sonuçlar çerçevesinde öneriler şöyle

- Hizmet yoğun sektörlerin başında gelen bankacılık sektöründe işletmeler mevcut müşterilerinin istek ve ihtiyaçlarına önem vermeli, doğru zamanda doğru şekilde bu istek ve ihtiyaçları karşılamalıdır.

- İşletmeler müşterilerinin özel istek ve ihtiyaçlarına yönelik kişiselleştirilmiş hizmet veya hizmet paketleriyle onlara işletme için özel olduklarını hissettirmelidirler.

- Günümüz teknolojisinin sağladığı imkânlardan yararlanarak güncel müşteri bilgisini içinde bulunduran kendilerine has veri tabanlarını oluşturmalıdırlar.

- Faaliyette bulundukları sektörün müşteri potansiyelini iyi analiz etmeli ve hedef pazarın ihtiyaçlarını önceden tahmin ederek yeni hizmet karmalarıyla rakipleri karşısında fark yaratmalıdırlar.

- Müşteri ilişkileri yönetimi kavramının önemini anlamalı ve bünyesinde bulunan bütün çalışanları ile birlikte bir süreç olan müşteri ilişkileri yönetimini en iyi şekilde yönetmelidirler. 
- Müşterileri ile sadece iş hakkında ilişkiler kurulmamalı, iş dışında müşterilerle özel günler, özel durumlar ve manevi değerler paylaşılmalıdır.

- Müşterileri üzerinde güven duygusunu oluşturmalı, işletmeye bağlılıklarını artırmalı ve sadık müşterilerinin işletmeden ayrılmaması için gerekli fedakârlıkları yapmalıdırlar.

- Müşterilerle uzun dönemli ilişkiler kurularak karlılığın uzun döneme yayılmasını hedeflemelidirler.

- Banka yöneticileri personelin verimliliğini arttırmaya yönelik girişimlerde bulunmalıdır.

- Yöneticiler tarafından personel memnuniyeti sağlanmalı, bunun sonucu olarak personel tarafından müşterilere kaliteli hizmet anlayışı yansıtılmalıdır.

- Araştırmacılar tarafından konunun önemi vurgulanmalı ve daha genel sonuçların elde edilebileceği araştırmalar yapılmalıdır.

- Araştırmacılar müşteri ilişkileri yönetimi hakkındaki yeni gelişmeleri takip etmeli ve bunlara araştırmalarında yer vermelidir.

Sonuç olarak, araştırma kapsamında elde bilgiler ışı̆̆ında bankacılık sektöründe uygulanan müşteri ilişkileri yönetimi uygulamalarının müşteri sadakati üzerinde etkili olduğu anlaşılmıştır. En çok önem verdiği kriterin hizmet sunumlarıyla ilgili olduğu görülmüştür. Katılımcıların demografik özelliklerine bakıldığında cinsiyet, eğitim ve meslek değişkenlerinin anlamlı farklılıklar gösterdiği sonucuna varılmıştır.

\section{KAYNAKÇA}

Aktepe, C., Baş, M. ve Tolon, M. (2009). Müşteri İlişkileri Yönetimi. Ankara: Detay Yayıncılık.

Aracı, E., Bulut, Z., Onaran, B. ve Koçak, N. (2014). "Fark Yaratan Uygulamalar Perspektifinden Seyahat Acentelerinde İlişkisel Pazarlama Faaliyetlerini Anlamak", Ege Akademik Bakış Dergisi, 14(4): 559-570.

Avcıkurt, C., Köroğlu, Ö. (2006).'Termal Otel İşletmelerinde Müşteri Sadakatini Artıran Nitelikleri Belirlemeye Yönelik Bir Alan Araştırması", Seyahat Ve Otel İşletmeciliği Dergisi, 3 (1): 5-16.

Baksi, A., (2014). "Relationship Management: Dimensions for Tourism", Scms Journal Of Indıan Management, 11(1): 80-96.

Bayuk, M. N., ve Küçük, F., (2007). “Müşteri Tatmini ve Müşteri Sadakati İlişkisi”, Marmara Üniversitesi İktisadi ve İdari Bilimler Fakültesi Dergisi, 22, (1):285-292.

Bircan K., Acayıp, E., ve Okursoy, A., (2014). “Bankacılık Sektöründe Müşteri İlişkileri Yönetimi Ve Çalışanlar Tarafından Değerlendirilmesi", Ekev Akademi Dergisi, 18(58):647-662.

Burnett, K., (2001). "Key Customer Relationship Management", Great Britain: , Pearson Education Limited.

Büyüköztürk, Ş., (2002). "Faktör Analizi: Temel Kavramlar ve Ölçek Geliştirmede Kullanımı", Kuram ve Uygulamada Eğitim Yönetimi Dergisi, 32(32): 470-483. 
http://www.tdk.gov.tr/index.php?option=com_gts\&arama=gts\&guid=TDK.GTS.568c71eb9dfc26 .87029790, Erişim: 30.12.2015

Imhoft, C., Loftis, L., Riger, J., (2001). “Building the Customer-Centric Enterprise, Data Warehousing Techniques for Supporting Customer Relationship Management", Canada: Wiley Cumputer Publishing.

Karagöz, Y., ve Ekici, S., (2004). "Sosyal Bilimlerde Yapılan Uygulamalı Araştırmalarda Kullanılan İstatistiksel Teknikler Ve Ölçekler", C.Ü. İktisadi ve İdari Bilimler Dergisi, 5(1):39.

Karakaş Geyik, S., Gökçen, A., (2014). "Türkiye'de İnternet Servis Sağlayıcıları Sektöründe Müşteri Sadakati Ve Bileşenlerinin Yapısal Eşitlik Modellemesi İle İncelenmesi", Marmara University Journal of Economic \& Administrative Sciences, 36(2): 159-184.

Keınıngham, T., Vavra T. ve Aksoy L., WALLAR Henri (2006), "Sadakat Söylenceleri", İstanbul: Rota Yayıncilik.

Kotler, P., (2003).' Marketing Insights From A to Z"', USA: John Vailey and Sons Inc.

Liyun, Q., Keyi, W., Xiaoshu, W., ve Fangfang, Z., (2008).“Research on the Relationship Among Market Orientation, Customer Relationship Management, Customer Knowledge Management And Business Performance", Management Science And Engineering, 2(1):31-37.

Nakip, M., (2006). "Pazarlama Araştırmaları Teknikler ve (SPSS Destekli) Uygulamala", Ankara: Seçkin Yayınları.

Oyman, M. (2002). “Müşteri Sadakati Sağlamada Sadakat Programlarının Önemi”, Kurgu Dergisi, 19: 169-185.

Öz, E., Özdağoğlu, G. ve Özdağoğlu, A. (2008). "Müşteri Sadakatinin Sağlanmasında Müşteri İlişkileri Yönetiminin Önemi: İzmir'de Bir Hipermarket Araştırması" Atatürk Üniversitesi İktisadi ve İdari Bilimler Dergisi, 22(1): 367-387.

Özilhan, D. (2010). "Müşteri İlişkileri Yönetimi (MiY) Uygulamalarının İşletme Performansına Etkileri", Gümüşhane Üniversitesi Sosyal Bilimler Enstitüsü Elektronik Dergisi, 1(1): 1830.

Özkan, E., Yıldız, S., (2015).'”Müşteri Sadakati İle Ağızdan Ağıza İletişimin Tüketici Satın Alma Davranışlarına Etkisi: Elektronik Eşya Sektöründe Bir Uygulama", Uluslararası İktisadi ve İdari İncelemeler Dergisi, 359-380.

Saydan, R. (2004). "1900'lerin İlk Yillarında Ford - General Motors Rekabeti (Üretim ve Pazarlama Anlayışının Karşılaştırılması)" Balıkesir Üniversitesi Sosyal Bilimler Enstitüsü Dergisi, 7(11):153-159.

Seçkin Z., Demirel Y., (2009). "Küresel Rekabetin Zihinsel İzdüşümü: Kavram Satmak", Elektronik Sosyal Bilimler Dergisi, 8(28): 175-186.

Swift, R. S., (2001), Accelerating Customer Relationships, New Jersey: Prentice Hall PTR A Pearson Education Company.

Yang, Z. ve Peterson, R. T., (2004), "Customer Perceived Value, Satisfaction, and Loyalty: The Role of Switching Costs", Psychlogy-Marketing, 21 (10):799-822. 
Yurdakul, M. ve Karahan, O. M. (2010). “Müşteri İlişkileri Yönetimi (CRM) Ve Ulaşım Sektöründe Bir Uygulama: İşletme Çalışanlarının Müşteri İlişkileri Yönetimi'ne Ve Müşterilerine Bakış Açılarının Belirlenmesi" Dumlupınar Üniversitesi Sosyal Bilimler Dergisi, 28: 133-145. 